\title{
The use of plant bioactive compounds to reduce greenhouse gas emissions from farmed ruminants
}

Cécile Martin, Vincent Niderkorn, Gaëlle Maxin, INRAE, France; Jessie Guyader, INRAE-ADM NEOVIA, France; Maguy Eugène and Diego P. Morgavi, INRAE, France

\begin{abstract}
Integrating the animal production sector into 'one health' is more relevant than ever: health care for humans, animals and the environment should be considered in a systemic and unified approach. In this global context, the use of natural substances in animal nutrition is a promising strategy for promoting an environmentfriendly livestock farming that considers feed efficiency and animal health, but also consumer safety and acceptance.

This review focusses on the opportunity to use plant bioactive compounds in ruminant diets for their potential to mitigate greenhouse gas emissions, particularly enteric methane. Nitrous oxide emissions related to urinary nitrogen waste are addressed when information is available. The main families considered are plant lipids and plant secondary compounds (tannins, saponins, halogenated compounds and essential oils). The effects of these compounds in vivo, their mechanisms of action, and their potential adoption on farms are discussed, and future trends in this research area are highlighted.
\end{abstract}

Key words: phytocompounds; nutrition; ruminant; greenhouse gases; environment

\section{Introduction}

2 Families of plant bioactive compounds

3 Case studies

4 Outstanding questions/future trends in research

5 Where to look for further information

\section{References}

\section{Introduction}

Livestock farming activities account for $14.5 \%$ of global greenhouse gas (GHG) emissions of anthropogenic origin (Gerber et al., 2013). Concerning the ruminant livestock sector, the largest contribution is from cattle and sheep mainly in the form of methane $\left(\mathrm{CH}_{4}\right)$ and nitrous oxide $\left(\mathrm{N}_{2} \mathrm{O}\right)$ emissions, which represent, in carbon equivalent, $44 \%$ and $30 \%$ of GHG emissions, respectively. Methane has a digestive (enteric) origin in ruminants, and is mostly eliminated into the atmosphere by eructation. During the microbial fermentation process of feeds in the rumen (bacteria, protozoa, fungi), hydrogen $\left(\mathrm{H}_{2}\right)$ is produced and is immediately used by archaea methanogens to reduce carbon dioxide into $\mathrm{CH}_{4}$. Nitrous oxide is produced in the soil during microbial processes (nitrification and denitrification) of urinary nitrogen (N) (urea and ammonia) excreted by ruminants (De Klein and Eckard, 2008; Selbie et al., 2015). Both enteric $\mathrm{CH}_{4}$ emissions and urinary $\mathrm{N}$ waste represent a loss of dietary energy (2-15\%) and $\mathrm{N}(75-95 \%)$ ingested, which could be otherwise available for animal production (Hristov et al., 2013b). Therefore, decreasing enteric $\mathrm{CH}_{4}$ emissions and $\mathrm{N}$ excretion from ruminants is important for reducing the environmental impact of ruminant production and for improving feed efficiency and the sustainability of this sector.

Compounds produced by the secondary metabolic processes of plants have been used for medicinal purposes by humans since antiquity (Wink, 2015). Research on the use of compounds in animal production increased when the use of antibiotics as growth promoters was banned in Europe and other parts of the world in 
the mid-2000s. The potential use of plant bioactive compounds in animal nutrition to reduce $\mathrm{CH}_{4}$ emissions and $\mathrm{N}$ waste is the subject of renewed interest as they are seen as a natural alternative to chemical additives, and are well perceived by consumers. Some plant compounds have marked biological activity and, depending on their concentration in ruminant diets, can have positive or negative effects on animal responses. Plant bioactive compounds are promoted as improving health (antiparasitic, reduce bloating, antioxidant) and performance ( $\mathrm{N}$ use efficiency). Conversely, they can decrease intake and diet digestibility (Mueller-Harvey, 2006) and can be toxic to animals (Reed, 1995).

We reviewed current information on the use of plant bioactive compounds in ruminant nutrition to promote livestock farming that is more environmentfriendly and efficient in the use of feed, but also compliant with consumer demands for quality and safety in animal products. We focussed on the potential of plant bioactive compounds to mitigate enteric $\mathrm{CH}_{4}$ production in ruminants and, when information is available, $\mathrm{N}$ waste. The main families of compounds considered as plant lipids are secondary compounds that are tannins, saponins, halogenated compounds and essential oils. Priority was given to information from in vivo studies by exploring the ability of plant compounds to positively modulate ruminant responses, but also their mechanisms of action, and utilization on farms. We selected two case studies showing the value of growing and using sainfoin forage in ruminant diets to decrease GHG emissions at farm scale, and of combining dietary strategies with different modes of action to increase enteric $\mathrm{CH}_{4}$ abatement. Future research on the use of plant bioactive compounds to reduce $\mathrm{GHG}$ emissions from farmed ruminants is also considered.

\section{Families of plant bioactive compounds}

\subsection{Lipids}

Lipids have a high nutritional value. The primary reason to use lipids in diet of ruminants was to increase the potential production of animals and to improve quality of meat and dairy products in terms of fat content and composition. However, an excessive dietary fat supplementation (> 7\% dry matter [DM]) can affect microbial fermentation and fibre digestion in the rumen (Palmquist and Jenkins, 2017). The variable effects of lipids on ruminal fermentation usually are attributed to differences in their lipid structure (Bayat et al., 2018; Vargas et al., 2020). One factor is their degree of unsaturation, because unsaturated fatty acids (from oleaginous oils or seeds, by-products such as residues from food processing plants) inhibit fermentation more than saturated fatty acids. Commercial inert lipids (e.g. calcium salts of saturated fatty acids) are rumen bypass fats, which do not affect the fibre digestion in the rumen at normal levels of supplementation in the diet.

Lipids are a proven dietary strategy for reducing $\mathrm{CH}_{4}$ emissions from ruminants whose effectiveness depends on many factors, such as the dose, the source and the mode of distribution (Martin et al., 2010; Beauchemin et al., 2020).

Meta-analyses agree that the $\mathrm{CH}_{4}$-mitigating effect of lipids are dosedependent (Giger-Reverdin et al., 2003; Eugène et al., 2008; Grainger and Beauchemin, 2011; Doreau et al., 2011): the decrease in $\mathrm{CH}_{4}$ emissions (g/kg DM intake [DMI]) varies between $1 \%$ and $7 \%$ per $10 \mathrm{~g} / \mathrm{kg} \mathrm{DM}$ added fat in the diet. For low doses of dietary added lipids (<2\% DM), the mitigating effect was not systematic in cattle (Chung et al., 2011; Veneman et al., 2015). For high doses of added dietary lipids, the decrease is linear in cattle with rapeseed oil $(0,5.4,9.5 \%$ added lipids; Jentsch et al., 1972) and coconut oil (0, 1.3, 2.7, 3.3\% added lipids; Hollmann et al., 2012) or quadratic in sheep with coconut oil (0,3.5, 7\% added lipids; Machmüller and Kreuzer, 1999). In dairy cows, many trials have shown the decreasing effect of lipids on methanogenesis (Martin et al., 2016; Bayat et al., 2018; van Gastelen et al., 2017) with different foragebased diets. The dose-response effect of extruded linseed (0, 1.8, 3.6, $5.4 \%$ added lipids) on $\mathrm{CH}_{4}$ emissions was more substantial with a corn silage-based diet compared to a hay-based 
diet (Martin et al., 2016). This more marked effect on methanogenesis was related to the adverse effects of lipids on animal performance (intake, digestibility, milk yield) with high doses of lipid supplementation.

The form of presentation of lipids also greatly influenced $\mathrm{CH}_{4}$ output from dairy cows: inhibition of methanogenesis increased with the theoretical availability of linseed lipids in the rumen (oil > extruded seed $>$ whole seed) (Martin et al., 2008). In practical conditions, extruded linseed is the most used form, because it is more readily available, easy to use, and less costly than oil and more efficient than crude linseed.

Concerning the source of lipids, conclusions of meta-analyses are not consensual: Grainger and Beauchemin (2011) did not find an effect of the source of lipids on $\mathrm{CH}_{4}$ emissions, whereas medium chain and polyunsaturated fatty acids were more potent than others in the meta-analysis of Doreau et al. (2011). In addition, the $\mathrm{CH}_{4}$-mitigating effect of extruded linseed (2-3\% added lipids) persisted for up to 1 year in dairy cows fed diets based on grazed pasture (80\%) or grass silage (60\%) (Martin et al., 2011). The persistency of this effect is very important for practical use.

The modes of action of lipids in mitigation of ruminal methanogenesis are multiple (Martin et al., 2010). A common effect for all lipids is that when carbohydrates are substituted by lipids, as lipids are not fermented in the rumen they do not contribute to $\mathrm{H}_{2}$ production, unlike the carbohydrates they replace. Moreover, lipids have a toxic effect on some microbial populations (Popova et al., 2011; Vargas et al., 2020), more particularly on $\mathrm{H}_{2}$-producing microbes (cellulolytic bacteria and protozoa), and reduce the metabolic activity of archaea methanogens by limiting $\mathrm{H}_{2}$ availability and consequently $\mathrm{CH}_{4}$ production. Ruminal biohydrogenation of unsaturated lipids may also help decrease methanogenesis, but the $\mathrm{H}_{2}$ sink function of this biohydrogenation process was estimated to be negligible (i.e. 1-2\%) based on stoichiometric (Czerkawski, 1986) and modelling (Mills et al., 2001; Giger-Reverdin et al., 2003) approaches.

Adding fat supplements in a proper dose to ruminant diets is a real opportunity to persistently reduce enteric $\mathrm{CH}_{4}$ emissions without altering animal performance. This dietary strategy can be immediately implemented on commercial farms, especially if the quality of the meat and milk produced is improved, as is the case with unsaturated lipid sources. Most of the time, lipids are added in mixed diets as oil, oilseeds or food by-products, which limits their utilization for grazing ruminants. Notwithstanding, the use of lipids as feed ingredients in ruminant diets is relatively costly; if they are not locally produced, they may have a higher carbon footprint, which should be considered before adopting them. The combination of lipids with other dietary strategies has the potential to further reduce enteric $\mathrm{CH}_{4}$ emissions (see case study).

\subsection{Secondary compounds}

\subsubsection{Tannins}

Among the polyphenolic compounds, a special emphasis has been placed on the effects of tannins as they may act at several levels to reduce GHG emissions from ruminants.

First, the well-known ability of tannins to bind dietary proteins and reduce rumen proteolysis results in an increase of $\mathrm{N}$ duodenal flow and a shift from urinary to faecal $\mathrm{N}$ excretion (Aufrère et al., 2008; Theodoridou et al., 2010). As urinary $\mathrm{N}$ deposition results in $\mathrm{N}_{2} \mathrm{O}$ emissions that are much higher than those arising from faecal $\mathrm{N}$ deposition (Luo and Kelliher, 2010), incorporating tannins in ruminant diets has great potential to decrease these emissions. In addition, a direct application of tannin extract (rather than feeding it) to barns reduces urease activity thereby decreasing ammonia loss from dairy barn floors (Powell et al., 2011). Finally, if tannins are from forage legume species, such as sainfoin (Onobrychis viciifolia), birdsfoot trefoil (Lotus corniculatus) or sulla (Hedysarum coronarium), their ability to fix and transfer atmospheric $\mathrm{N}$ into the soil reduces the use of $\mathrm{N}$ fertilizers, themselves a source of $\mathrm{N}_{2} \mathrm{O}$ emissions through microbial nitrification and denitrification processes (Bouwman, 1996). 
Second, an abundant literature shows that tannins in ruminant diets decrease enteric $\mathrm{CH}_{4}$ emissions (review of Piluzza et al., 2014). The effect of these molecules on methanogenesis is highly variable between studies according to their nature (condensed or hydrolyzable), their chemical structure (molecular weight), but especially the dose ingested by the animal and the form of presentation. Given the extremely diverse structure of tannins in the plant kingdom, efforts have recently been made to understand their structure/activity relationships to facilitate their applicability (Mueller-Harvey et al., 2019). This aim was achieved thanks to remarkable progress in chemical analysis of both condensed (Zeller, 2019) and hydrolyzable tannins (Engström et al., 2019).

Using purified hydrolyzable (from chestnut and sumach) and condensed tannins (from mimosa and quebracho), Jayanegara et al. (2015) showed in vitro that hydrolyzable tannins have a greater effect in reducing $\mathrm{CH}_{4}$ emissions with less detrimental effect on digestibility than condensed tannins. Rira et al. (2019) reported the same conclusion with tropical forages tested in vitro: hydrolysable tannin-rich sources (Acacia nilotica) were more effective in supressing methanogenesis than condensed tannins-rich sources (Calliandra calothryrsus and Leucaena leucocephala). In addition, combination of these plants did not highlight synergies between these two types of tannins. The type of molecular interaction that drives the protein binding capacity of tannins is highly related to the structure of both tannins and proteins. Protein precipitation increases consistently with the mean degree of polymerization and tends to be higher with prodelphinidin-rich condensed tannins due to a greater number of potential hydrogen-bond participants available to interact with proteins (Zeller, 2019). The ability of hydrolyzable tannins to form insoluble complexes with protein seems to be related to their molecular weight (oligomers superior to monomers), but also to the type and number of functional groups (e.g. galloyl groups) in monomers (Engström et al., 2019).

Using purified condensed tannins of different structures from eight plants, Huyen et al. (2016b) showed in vitro that the proportion of prodelphinidins in condensed tannins had the largest effect on $\mathrm{CH}_{4}$ production and fermentation characteristics, followed by the average polymer size. Other in vitro studies have shown that condensed tannins with a high degree of polymerization are more potent in lowering $\mathrm{CH}_{4}$ production and the diversity and abundance of rumen methanogens (Hatew et al., 2016; Saminathan et al., 2016). Similarly, Baert et al. (2016) investigated in vitro how the degree of oligomerization of purified ellagitannins, an important family of hydrolyzable tannins, can influence their ability to alter ruminal fermentation including $\mathrm{CH}_{4}$ production. They showed that large oligomers have more detrimental effects on gas production and volatile fatty acids (VFA) than small oligomers, while being similarly effective in their ability to decrease $\mathrm{CH}_{4}$ production.

The meta-analysis conducted by Jayanegara et al. (2012), including data from a total of 30 experiments (both in vitro and in vivo), helped to partly clarify the underlying mode of action of tannins on methanogenesis. These authors reported that related $\mathrm{CH}_{4}$ reduction is associated with reduced OM digestibility, especially fibre, because of a decreased number/activity or impaired substrate adhesion of fibrolytic microbes. This inhibitor effect of tannins on fibrolysis was more marked for condensed tannins than for hydrolysable tannins in dairy ewes (Buccioni et al., 2015). Recently, Costa et al. (2018) reported in sheep that gram-positive specialized fibrolytic bacteria ( $R$. albus, $R$. flavefaciens and B.proteoclasticus) were more affected by condensed tannins than gramnegative bacteria ( $F$. succinogenes, $S$. ruminantium and $P$. bryantii), with a decrease in rumen volatile fatty acids concentration, mostly acetate.

Methane emissions also declined when expressed per $\mathrm{kg}$ DOM, suggesting that other mechanisms account for the anti-methanogenic activity of tannins Jayanegara et al. (2012). Tannins have been shown to directly inhibit $\mathrm{H}_{2}$-using methanogens in the rumen of sheep (Liu et al., 2011) and beef cattle (Yang et al., 2017). This direct effect of tannins on methanogens microbiota, without affecting fibre digestion, would be more specific to hydrolysable tannins as reviewed by Vasta et al. (2019).

The potential of tannins to reduce methanogenesis has been widely reviewed from in vitro and in vivo studies highlighting a large variability of data (reviews of Piluzza et al., 2014 and Vasta et al., 2019). Archimède et 
al. (2016) observed a linear relationship between condensed tannins content of three tropical-rich plants (Glyricidia sepium, Leucaena leucocephala, Manihot esculenta) and $\mathrm{CH}_{4}$ reduction in vivo. The potential of mitigation ranged between $13 \%$ and $36 \%$ in sheep fed a forage diet containing between $1.5 \%$ and $4.0 \% \mathrm{DM}$ of condensed tannins. The authors reported also a better palatability (and intake) of tannin-rich tropical plants and a strong decrease in $\mathrm{CH}_{4}$ emissions in animals fed the plants as pellets. Concerning hydrolysable tannins, their potential of mitigation ranged between $10 \%$ and $25 \%$ with sheep (Liu et al., 2011) and 11-30\% with beef cattle (Yang et al., 2017) fed diets containing 1-3\% DM of tannins from chestnut and pure hydrolysable tannins, respectively.

Few general equations of $\mathrm{CH}_{4}$ prediction concerning tannins, mostly derived from in vitro trials, are available because of the diversity of chemical analysis methods and types of tannins (Jayanegara et al., 2012). We conducted a quantitative review of the literature by meta-analysis to assess the specific effect of tannins (condensed or hydrolyzable) on in vivo $\mathrm{CH}_{4}$ emissions in ruminants (Eugène et al., 2019). Using an existing database (Methafour, INRA, 2018) on the effect of forages fed to ruminants on $\mathrm{CH}_{4}$ emissions, we were able to significantly improve the accuracy of the Eq. [1] based on animal-feeding level and forage diet composition to predict $\mathrm{CH}_{4}$ emissions, by taking into account the tannin content of the forage diets as mentioned in the Eq. [2]:

- $\quad$ Equation [1] for forage diets

$\mathrm{CH} 4 / \mathrm{DOM}=34.95-4.05 \mathrm{FL}+0.027 \mathrm{NDF}-0.010 \mathrm{DOM}$

$(n=412, \operatorname{nexp}=153$, RMSE $=3.1)$

- Equation [2] for forage diets containing tannins

$\mathrm{CH} 4 / \mathrm{DOM}=34.26-3.96 \mathrm{FL}+0.027 \mathrm{NDF}-0.008 \mathrm{DOM}-1.72 \log 10(1+\mathrm{TAN})$

$(n=398, n \exp =147$, RMSE $=3.1)$

where $\mathrm{CH}_{4} / \mathrm{DOM}$ is the $\mathrm{CH}_{4}$ production ( $\mathrm{g} / \mathrm{kg}$ digested organic matter [DOM]), $\mathrm{FL}$ is the feeding level (kg DM intake $\%$ liveweight), NDF is the NDF content ( $\mathrm{g} / \mathrm{kg} \mathrm{DM})$ and DOM is the DOM content $(\mathrm{g} / \mathrm{kg} \mathrm{DM})$ and TAN is the tannin content $(\mathrm{g} / \mathrm{kg} \mathrm{DM})$ of the diet, which is transformed on a logarithmic basis to account for its largely abnormal distribution (Sauvant et al., 2018).

The coefficients of regression of all variables remain stable between Eqs. [1] and [2], highlighting the specific effect of tannins on methanogenesis. Based on current scientific knowledge, we propose to use the coefficient of TAN in Eq. [2] to evaluate the average quantitative effect of tannins in vivo on $\mathrm{CH}_{4}$ emissions in all types of diets (Fig. 1). Our results confirm that $\mathrm{CH}_{4}$ mitigation increases with the dose of tannins in the diets (Jayanegara et al., 2012). Unfortunately it is not possible to give a minimum threshold of tannins content to observe an effect on methanogenesis because it is modulated by the FL, NDF and DOM content of the diet. 


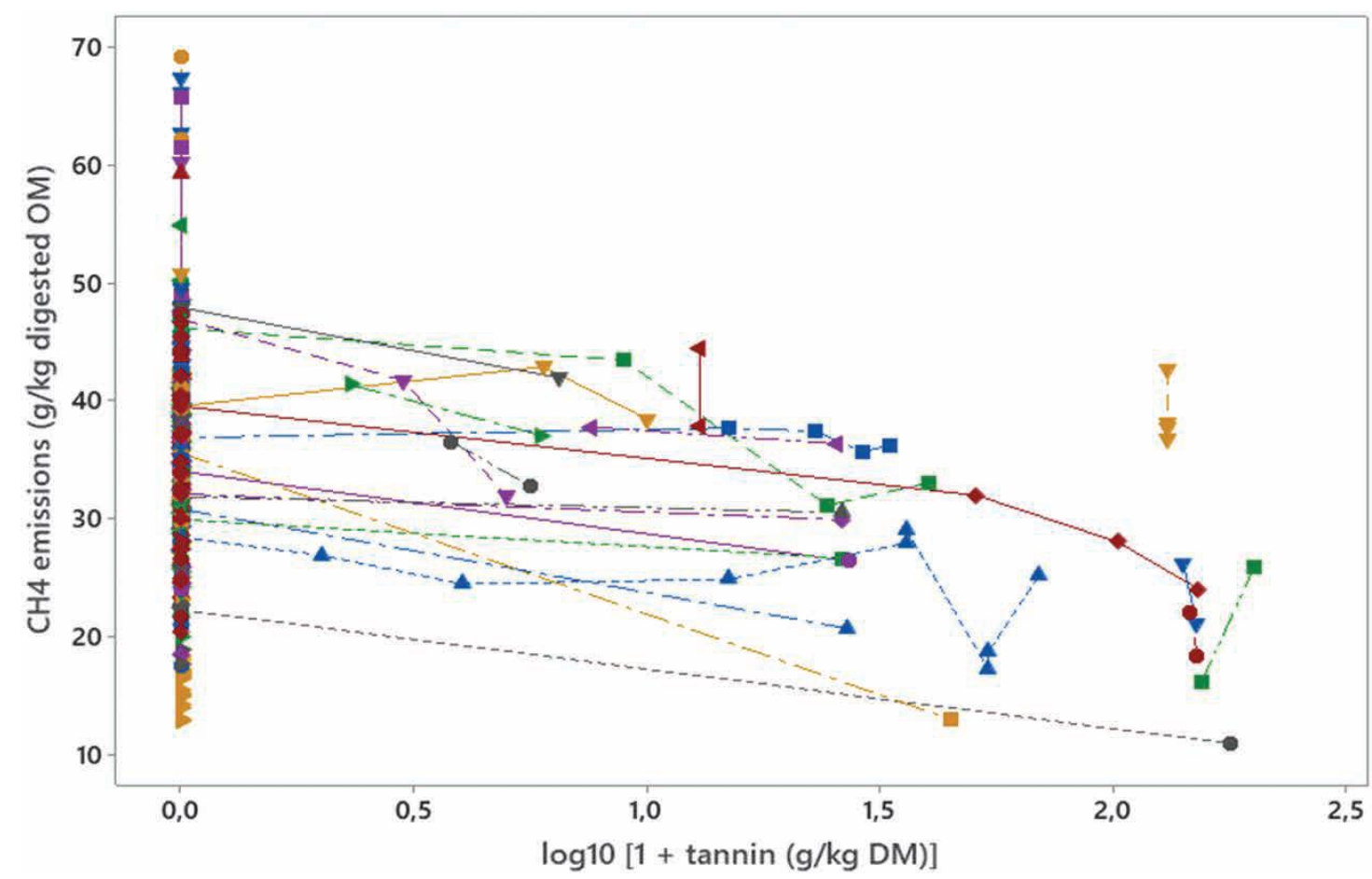

Figure 1 Relationship between methane emissions ( $\mathrm{g} / \mathrm{kg}$ digested OM) and tannin content ( $\mathrm{g} / \mathrm{kg} \mathrm{DM})$ in the diet.

Tannins are consumed by animals as plants or added as an extract to rations. The use of foddercontaining tannins is particularly relevant for grazing ruminants since many forage legumes are rich in tannins. New insight into the chemical structure of tannins helps to explain the inconsistencies of effects on protein-binding ability and on $\mathrm{CH}_{4}$ emissions reported in the literature. Despite this progress, there are still questions to address concerning the use of tannin-rich resources on farms. Considering the variability in tannin activity, one solution could be the production of batches of feeds or plant extracts analysed before their marketing. Also, in the context of agro-ecological ruminant production systems, the use of integrated solutions such as tannin-containing legumes offers opportunities to act at multiple levels of GHG production (see case study).

\subsubsection{Saponins}

Saponins are secondary metabolites present in seeds, leaves and roots of a broad variety of plants. They are usually classified into two major classes, triterpenoids (soy, pea, garlic, sunflower, panama bark) and steroid glycosides (e.g. oat, eggplant, tomato, yucca, fenugreek), but Vincken et al. (2007) refined their classification in 11 main categories based on their carbon skeleton. Despite some negative effects upon feeding in animal nutrition (increased membrane permeability of erythrocytes and enterocytes, or impaired animal production and reproduction; reviews of Addisu and Assefa, 2016; Francis et al., 2007), saponins can have beneficial effects on rumen fermentation and animal health when used in a proper dosage. Among others, saponins can decrease in vivo degradability of feed protein, avoid $\mathrm{N}$ accumulation and increase efficiency of microbial protein synthesis in the rumen (Francis et al., 2007; Patra and Saxena, 2009). In addition, saponins from Quillaja saponaria (known as quillaja saponins), Yucca schidigera (known as yucca saponins) and Camellia sinensis or assamica (known as tea saponins) have been extensively studied for their mitigating effect on rumen methanogenesis. Other saponin sources have shown interesting $\mathrm{CH}_{4}$-mitigating impacts: mangosteen peel powder (Wanapat et al., 2014) and alfalfa saponins (Klita et al., 1996), but these effects need to be confirmed. 
The underlying mechanism mainly involves an inhibitory effect towards rumen microbes and more particularly protozoa, which produce large amounts of $\mathrm{H}_{2}$ and are known to live in symbiosis with methanogenic archaea (Guyader et al., 2014; Morgavi et al., 2010). The membrane-disrupting activity of saponins would explain their toxic effect on protozoa through the formation of complexes with sterols present in the protozoal cell wall, thereby inducing cell lysis (Morgavi et al., 2010).

The $\mathrm{CH}_{4}$ mitigation potential of saponins depends on the dose and source of saponins (Patra and Saxena, 2010). Most studies on this subject have been conducted in vitro. In a meta-analysis combining 23 studies, Jayanegara et al. (2014) reported a linear inhibiting dose-response effect of saponins towards methanogenesis (tested dosage between $0 \%$ and $0.6 \%$ DM). Compared with quillaja and tea saponins, yucca saponins induced the greatest reduction in $\mathrm{CH}_{4}$ expressed as $\mathrm{mL}$ per unit of incubated substrate. However, when expressed as a percentage of total gas produced, all tested saponin sources were statistically similar, and produced less $\mathrm{CH}_{4}$ than the control. However, in vivo results are not as clear. Using up to 1.4\% DM of quillaja saponins in the diet, Pen et al. (2007) and Holtshausen et al. (2009) did not observe a difference in $\mathrm{CH}_{4}$ emissions of sheep and dairy cows, respectively. Patra and Saxena (2009) summarized published papers studying the in vivo effect of saponins, including yucca saponins, on fermentation parameters. Only two papers out of five showed a significant reduction $(-14 \%$ in Santoso et al., $2004 ;-7 \%$ in Wang et al., 2009) in methanogenesis with sheep fed a diet containing $1.3 \%$ DM of yucca saponins. Similarly, the effect of tea saponins seems to be highly variable. With similar dosages comprised between $0.4 \%$ and $0.8 \%$ DM, three papers reported a decrease in $\mathrm{CH}_{4}$ yield $(\mathrm{g} / \mathrm{kg} \mathrm{DMl}$ ) on adult sheep $(-17 \%$ in Yuan et al., 2007; $-26 \%$ in Zhou et al., 2011) and on lambs (-69\% in Mao et al., 2010). More recent papers showed an absence of effect on steers (Li and Powers, 2012) and non-lactating cows (Guyader et al., 2015), or even an increase in $\mathrm{CH}_{4}$ emissions on lactating dairy cows (+18\% in Guyader et al., 2017) with the same dosages. Concerning the effect of tea saponins on other digestion parameters, data are scarce but mostly indicate an absence of effect on nutrient digestibility or N balance. However, milk yield in dairy cows (Guyader et al., 2017) and average daily weight gain in growing steers (Li and Powers, 2012$)$ decreased $(-18 \%$ and $-80 \%$, respectively) as a consequence of lower intake in both studies $(-12 \%$ and $-27 \%$, respectively). However, $0.4 \%$ tea saponin in a Chinese wild rye-based diet did not affect feed intake or growth of lambs (Mao et al., 2010).

Four main reasons might explain the variable effect of saponins on methanogenesis and limit their utilization in animal nutrition. The quality of saponins is an important criterion for their $\mathrm{CH}_{4}$-mitigating efficiency (Jayanegara et al., 2014). Plant maturity, geographical area of production and extraction methods are three parameters affecting the final concentration and quality of saponins ( $\mathrm{Li}$ and Powers, 2012). Denaturation of saponins might also be possible during pelleting processes. Indeed, a modification of the miscellaneous structure of quillaja saponins was observed after heating from $20^{\circ} \mathrm{C}$ to $60^{\circ} \mathrm{C}$ (Mitra and Dungan, 1997). Guyader et al. (2015) assumed that denaturation was one possible explanation for the lack of effect on $\mathrm{CH}_{4}$ production of tea saponins fed to nonlactating dairy cows.

The transient effect of saponins on rumen microbes is another limitation for their utilization. After adaptation, rumen bacteria are able to separate the active compound of saponins (sapogenin) from the sugar moiety, leading to their inactivation (Ramos-Morales et al., 2017). Newbold et al. (1997) supplemented sheep with saponins from foliage of an African multipurpose tree, Sesbania sesban. Protozoa concentrations dropped by $60 \%$ after 4 days, but the population recovered after 10 days. However, the time for adaptation of rumen microbes seems to be dependent upon the source of saponins: the antiprotozoal effect of saponins from Sapindus rarak was persistent over 105 days in sheep (Wina et al., 2006). Chemical modification of their structure to avoid microbiota adaptation may maximize the $\mathrm{CH}_{4}$-mitigating potential of saponins (Ramos-Morales et al., 2017).

The $\mathrm{CH}_{4}$-mitigating response seems to be dependent on the composition of the basal diet. For instance, in a study with young Holstein males, Wang et al. (2019) concluded that changes in the ruminal microbial community with tea saponin supplementation were different between alfalfa-, hay- or soybean hullbased diets. Given that the 
protozoal community is strongly affected by the basal diet, Patra and Saxena (2009) assumed that the dietdependent effect of saponins is related to their selectivity for specific protozoal species.

Finally, the last challenge in saponin utilization is their impact on feed intake. Reduced intake has been reported following dietary supplementation with tea saponins in lactating dairy cows (Guyader et al., 2017) and steers (Li and Powers, 2012). Nevertheless, this drawback is not systematic: among the 43 papers compiled by Patra and Saxena (2009), who did not include recent papers on tea saponins, only two reported a decrease in feed intake with yucca saponins supplementation.

The effects of saponin supplementation in the diets of ruminants are highly contrasted. The conditions in which yucca, quillaja and tea saponins reduce $\mathrm{CH}_{4}$ emissions from ruminants must be refined (optimal dose, long-term persistency). In addition, given the wide variety of saponin structures, screening of other plants might highlight the beneficial effect of new sources available for localized markets. Before adoption by farmers, the potential effects of saponins on digestion efficiency and zootechnical performance should also be investigated in depth.

\subsubsection{Halogenated compounds}

Halogenated products (e.g. bromoform, dibromomethane, dichloromethane, bromochloroacetic acid, etc.,) exist naturally in seaweed at different concentrations, and much more in red and brown algae than in green ones. These compounds may be produced as defense against disease and marine herbivores, anti-oxidants or by-products of metabolic processes (Keng et al., 2020).

Different macroalgae have been shown to decrease in vitro $\mathrm{CH}_{4}$ production effectively (Dubois et al., 2013; Machado et al., 2014; Kinley and Fredeen, 2015). Among 20 tropical species screened, the red macroalgae, Asparagopsis taxiformis, was identified as the most efficient (Machado et al., 2014). Low doses (2\% OM incubated) of $A$. taxiformis almost eliminated in vitro $\mathrm{CH}_{4}$ production (Machado et al., 2016a), without any effect on forage digestibility (Kinley et al., 2016) and without compromising other fermentation parameters at a $5 \%$ OM supplementation rate (Roque et al., 2019a).

The $\mathrm{CH}_{4}$-mitigating effect of red seaweed Asparagopsis spp. (A. taxiformis and A. armata) was recently confirmed in three in vivo trials. Li et al. (2016) reported a consistent (over a 72-day period) and dose-dependent reduction in $\mathrm{CH}_{4}$ emissions $(-50 \%$ to $-80 \%)$ when adding $A$. taxiformis at $1-3 \%$ of diet $\mathrm{OM}$, respectively. In dairy cows, adding $A$. armata at $0.5 \%$ and $1 \%$ of diet $\mathrm{OM}$ reduced $\mathrm{CH}_{4}$ emissions ( $-26 \%$ and $-67 \%$, respectively) over 21 days while compromising animal performances (milk yield, intake) only at the high dose (Roque et al., 2019a). The last experiment in feedlot beef cattle tested $A$. taxiformis in a high grain diet at three inclusion levels $(0.05 \%$, $0.10 \%$, and $0.20 \%$ of diet OM) over a 90 -day period (Kinley et al., 2020). Steers receiving $0.10 \%$ and $0.20 \% A$. taxiformis demonstrated decreased $\mathrm{CH}_{4}$ emissions up to $-40 \%$ and $-98 \%$, and demonstrated weight gain improvements of $+53 \%$ and $+42 \%$, respectively. There was no negative effect on daily feed intake, feed conversion efficiencies, or rumen function, and no residues or changes in meat-eating quality were detected.

Bromoform is the most abundant natural product in Asparagopsis taxiformis and thus has been identified as the compound involved in $\mathrm{CH}_{4}$ reduction, even if combination of the different compounds may play a role in this reduction (Machado et al., 2016b). Halogenated compounds in Asparagopsis taxiformis appear to act as structural analogues of coenzyme $M$ and thus inhibit the final step of the methanogenesis pathway (Liu et al., 2011). It has been shown that the decrease in abundance of methanogens in the rumen was positively correlated with the decrease of methanogenesis and increase in $\mathrm{H}_{2}$ emissions (Machado et al., 2018; Roque et al., 2019a). Emissions of bromoform into the atmosphere may occur during the growth of seaweed or during desiccation processes (Keng et al., 2020), which would prevent - or at least greatly hamper - the farming of red seaweed on a commercial basis. 
Macroalgae have a tremendous potential to inhibit methanogenesis in ruminants at low doses of supplementation. Asparagopsis spp. are the most effective species. Further investigations are required to confirm a longterm persistency effect on methanogenesis and long-term safety in animal responses before adoption by farmers. In addition, widespread use of red seaweed for animal nutrition raises concerns about their contribution to biogenic halocarbon emissions and their impact on the environment (i.e. ozone depletion related to bromoform). The carbon footprint of each step of algae production (harvesting, drying process, delivery, etc.,) also needs to be considered for upstream emissions.

\subsubsection{Essential oils}

In addition to the compounds considered in previous sections, there are other plant bioactive compounds, collectively known as 'essential oils', that have the potential to mitigate $\mathrm{CH}_{4}$ and ammonia production in ruminants (Cobellis et al., 2016). The name essential oil is not specific; it mainly comprises a diverse group of terpene and phenylpropene compounds, but also organosulphur compounds (Benchaar and Greathead, 2011). There are thousands of compounds that are qualified as essential oils and many of them have been tested in vitro (reviewed by Calsamiglia et al., 2007; Hart et al., 2008; Benchaar and Greathead, 2011; Cobellis et al., 2016). However, for multiple reasons only a handful of these compounds have been pursued in animal studies. Many of the compounds tested decreased methanogenesis through a general reduction in feed degradation and fermentation in the rumen and, therefore, are not further considered in this chapter. The effect of some compounds was observed at high doses not compatible with their incorporation (as an extract or as the plant containing the active component) in the diet. In addition, for some compounds or plants there are issues of toxicity, palatability, cost and availability that preclude their utilization even for experimental purposes. Further, the majority of in vivo studies have tested the effects of essential oils on general production parameters and only a handful of them included measurements of enteric $\mathrm{CH}_{4}$ emissions (Cobellis et al., 2016). In this section, we will focus on those plant secondary compounds that were tested in vivo for their anti-methanogenic activity.

Most metabolites tested to reduce $\mathrm{CH}_{4}$ production in ruminants are naturally produced by plants to fend off microbial invasion. Compounds that are effective in vitro, such as eugenol, which is abundant in the essential oil of clove, and cinnamaldehyde, which is abundant in cinnamon (Macheboeuf et al., 2008; Patra and Yu, 2012), did not reduce $\mathrm{CH}_{4}$ emissions when tested on dairy cows (Benchaar, 2015; Benchaar et al., 2015). Carvacrol is a monoterpene with a phenol ring structure that is abundant in oregano and thyme. Oregano (Origanum vulgare) leaves fed to lactating dairy cows at doses of 250,500 or $750 \mathrm{~g} / \mathrm{d}$ decreased $\mathrm{CH}_{4}$ production by up to $-40 \%$ for the medium dose (Tekippe et al., 2011; Hristov et al., 2013a). But the $\mathrm{CH}_{4}$ measurements were done up to $8 \mathrm{~h}$ after feeding and the authors noted that 24-h continuous measurement is needed to validate the results. In another study on dairy cows, the use of oregano extract mixed into the diet at $0.056 \% \mathrm{DM}$ tended to reduce $\mathrm{CH}_{4} \mathrm{yield}(\mathrm{g} / \mathrm{kg} \mathrm{DMI})$ by $-22 \%$ (Kolling et al., 2018).

Flavonoids are a class of plant secondary compounds that have antimicrobial, anti-inflammatory and antioxidative functions. These compounds have been extensively studied in animal nutrition (Olagaray and Bradford, 2019). In studies with ruminants, supplementation of diets with flavonoids from mulberry decreased $\mathrm{CH}_{4}$ yield $(\mathrm{g} / \mathrm{kg}$ DMI) by $-11 \%$ in sheep (Ma et al., 2017). The main flavonoids of mulberry are quercetin glycosides and rutin, a glucorhamnoside of quercetin (Ju et al., 2018). In contrast, the use of pure rutin or rutin contained in buckwheat seeds did not have any effect on $\mathrm{CH}_{4}$ emissions in dairy cows (Stoldt et al., 2016). Catechins, flavonoids contained in green tea leaves, decreased $\mathrm{CH}_{4}$ emissions (g/kg digestible DMI) in dairy cows by $-18 \%$ (Kolling et al., 2018). Green tea also contains saponins that may have a synergistic effect in reducing $\mathrm{CH}_{4}$. Notwithstanding, a commercial purified catechin extract linearly decreased $\mathrm{CH}_{4}$ emissions in sheep by 7-13\% (Aemiro et al., 2016). Catechins have known antimicrobial activities including a toxic effect on protozoa (Aemiro et al., 2016), but they are also known $\mathrm{H}_{2}$ 
sinks that can compete with $\mathrm{CH}_{4}$ production in the rumen environment (Becker et al., 2014). For flavonoids in general, it is noted that those that have antiinflammatory functions in the host animal are not effective in reducing $\mathrm{CH}_{4}$ emissions or modulating microbial fermentation in the rumen (Olagaray and Bradford, 2019).

Sinigrin is a glucosinolate found in some plants of the Brassicaceae family, like black mustard and horseradish, which is naturally converted to allyl isothiocyanate when the plants are processed (Mohammed et al., 2004). The latter compound is responsible for the strong flavour of horseradish and low palatability if used as a feed additive (Mohammed et al., 2004). A coated additive would avoid the problem of palatability and provide a gradual release of the sinigrin. A cyclodextrin-coated horseradish oil added to the diet of steers decreased $\mathrm{CH}_{4}$ emissions by $-19 \%$. Although the mechanism of action is not well understood, the number of methanogens also decreased significantly. A parallel in vitro study showed a large increase in $\mathrm{H}_{2}$ associated with $\mathrm{CH}_{4}$ reduction (Mohammed et al., 2004), similar to that observed with specific inhibitors of methanogens or methanogenesis, such as garlic or halogenated compounds.

A particular mention is made for organo-sulphur compounds from garlic (Allium sativum). Sulphur compounds in garlic have both general antimicrobial properties and are specific inhibitors of the enzyme hydroxymethylglutaryl-CoA (HMG-S-CoA) reductase, which is essential for the production of the cell wall of archaea methanogens. These compounds remarkably reduce $\mathrm{CH}_{4}$ production in vitro (reviewed by Hart et al., 2008; Benchaar and Greathead, 2011). However, there are few reports describing the in vivo use of garlic oil or diallyl disulphide, the main component of garlic oil. A decrease of about $-8 \%\left(\mathrm{~g} \mathrm{CH}_{4} / \mathrm{kg}\right.$ digestible OM intake) was reported in sheep supplemented with garlic extract (Ma et al., 2016), whereas garlic leaves, which are normally discarded after harvesting the bulbs, reduced emissions by $-10 \%\left(\mathrm{~g} \mathrm{CH}_{4} / \mathrm{kg} \mathrm{DMI}\right)$ in sheep (Panthee et al., 2017).

Garlic oil combined with linseed oil reduced emissions in lambs, but the effect cannot be ascribed solely to garlic oil (Saro et al., 2018). Similarly, dried garlic combined with mangosteen peel rich in tannins and saponins reduced $\mathrm{CH}_{4}$ emissions in cattle (Manasri et al., 2012), but the effect is confounded. In contrast, no effect was observed in a study with diallyl disulphide, garlic oil or raw garlic (Klevenhusen et al., 2011; Patra et al., 2011). More recently, a commercial mixture of garlic and citrus extracts (Mootral) was tested in dairy cows with positive results (Roque et al., 2019b; Vrancken et al., 2019). These results are encouraging, but should be confirmed by further studies. For instance, in the work of Roque et al. the reduction in $\mathrm{CH}_{4}$ was observed in the last week of the 12-week study, but not before. In addition to the product mentioned above, there are several commercial products based on mixtures of essential oils that have been tested for their $\mathrm{CH}_{4}$-reducing activity. The most tested are CRINA Ruminants (DSM; mixture of essential oil components) and Agolin Ruminant (Agolin; mixture of coriander oil, eugenol, geranyl acetate and geraniol, among others) and XTRACT Ruminant (Pancosma; mixture of cinnamon, cloves and capsicum oleoresin from chili peppers). The first product showed no effect on $\mathrm{CH}_{4}$ emissions in beef cattle (Beauchemin and McGinn, 2006; Tomkins et al., 2015). The effect of Agolin Ruminant on dairy cows was recently evaluated in a meta-analysis (Belanche et al., 2020). A total of 23 in vivo experiments and on-farm studies were identified in which the additive was supplemented at $1 \mathrm{~g} / \mathrm{d} / \mathrm{cow}$. Of these, nine had records of enteric $\mathrm{CH}_{4}$ that showed an average decrease of $-8.8 \%,-12.9 \%$ and $-9.9 \%(\mathrm{~g} / \mathrm{kg}$ milk) without a negative effect on feed digestibility or milk yield. The effects were observed only after an initial period of adaptation of at least 4 weeks.

Anacardic acid is an akylphenolic compound that is found in the shell of the cashew nut. It has antimic activity, particularly against gram-positive bacteria. In the rumen, it decreased the numbers of $\mathrm{H}_{2}$ - and formateproducing bacteria such as Ruminococcus flavefaciens, Butyrivibrio fibrisolvens and Treponema bryantii, whereas succinate-producing bacteria such as Prevotella spp., Selenomonas ruminantium, Anaerovibrio lipolytica and Succinivibrio dextrinosolvens increased (Shinkai et al., 2012; Konda et al., 2019). Methanogen numbers also decrease with changes in the community composition (Shinkai et al., 2012; Kang et al., 2018). The use of cashew nut shell liquid (CNSL) as a feed additive reduced $\mathrm{CH}_{4}$ emissions in Holstein cows by $-19 \%$ and $-38 \%$ in a dosedependent manner (Shinkai et al., 2012). The anti-methanogenic effect of CNSL was also observed in Thai native 
cattle and buffaloes (Konda et al., 2019). These changes in $\mathrm{CH}_{4}$ were observed along with increases in propionate and decreases in acetate in the rumen. The technical grade CNSL (t-CNSL) is the main by-product of the cashew industry that does not contain anacardic acid, as during the production process it is converted into cardanol. The utilization of t-CNSL was not as effective at reducing enteric $\mathrm{CH}_{4}$ emissions in dairy cows (Branco et al., 2015), suggesting that anacardic acid is the main active component in CNSL.

Essential oils used to mitigate $\mathrm{CH}_{4}$ emissions and $\mathrm{N}$ waste have been extensively studied mainly in vitro, but validation of the results in vivo is still scarce. The use of cocktails of molecules in most in vivo studies makes it difficult to identify active molecules and to understand the mechanisms of action. Work remains to be done to demonstrate the effectiveness of certain essential oils and to consider their synergistic or antagonistic interaction with other compounds. For most compounds, there is also a need to assess their efficacy in the long term, not only in reducing $\mathrm{CH}_{4}$ emissions, but also in the production and welfare of animals, to facilitate adoption by farmers.

\section{Case studies}

\subsection{Sainfoin, a traditional forage legume containing condensed tannins}

Several methods can be used to deliver tannins to the animals, using crude extracts from plants, by-products, wood or whole plants. Agro-ecological and local solutions that integrate several dimensions of ruminant nutrition can decrease GHG emissions at multiple levels, while improving protein self-sufficiency and reducing inputs such as fertilizers and drug treatments (Soussana et al., 2015). In this context, one option is to include legume species containing tannins in animal diets. Recently, a European multidisciplinary research consortium of agronomists, plant breeders, ruminant nutritionists, veterinarians and experts in tannin chemistry focussed on sainfoin, a traditional forage legume (Mueller-Harvey et al., 2019). Here, we present the specific results of this project regarding the potential of sainfoin to decrease GHG emissions (Fig. 2).

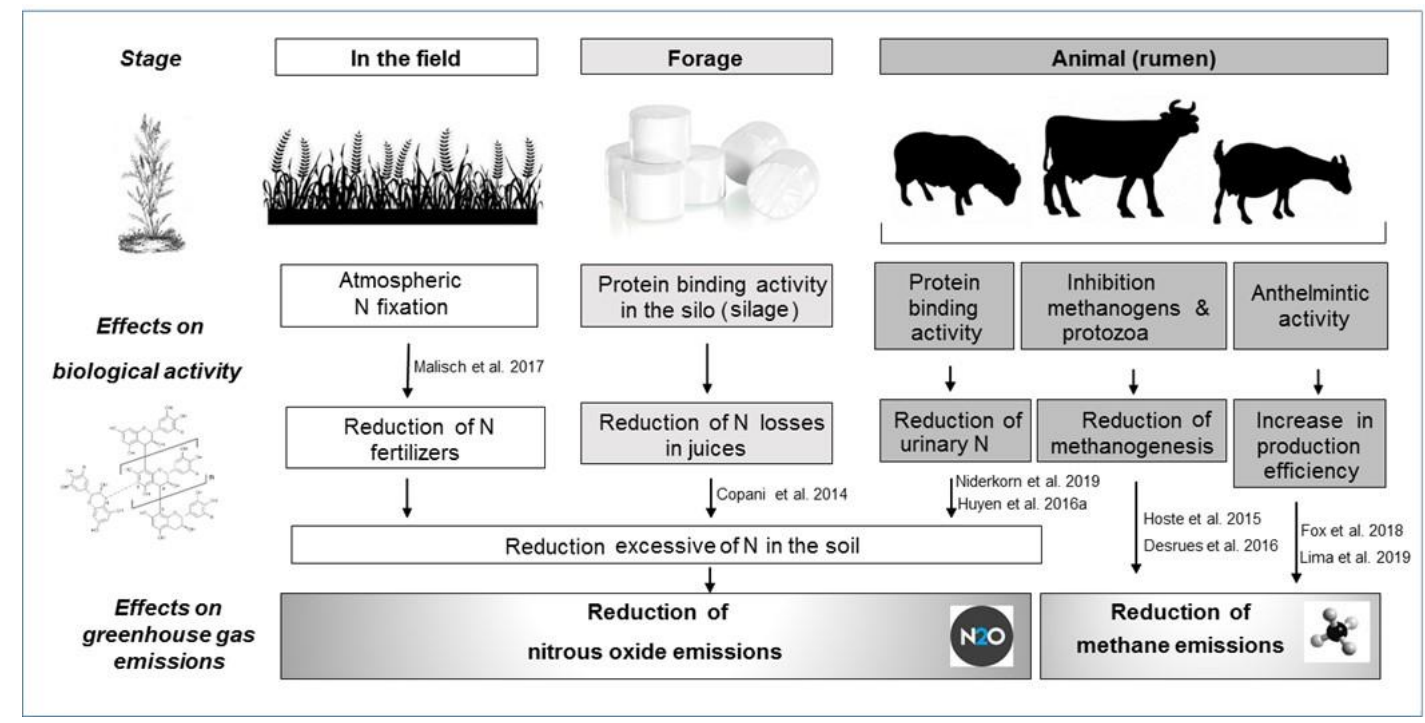

Figure 2 Multiple effects of growing and using sainfoin in ruminant diets to decrease greenhouse gas emissions.

A first interesting result was obtained at the field level, where symbiotic $\mathrm{N}$ fixation by sainfoin was shown to be comparable to the major $\mathrm{N}$-fixing species such as white and red clover without treatment with a commercial rhizobia product (Malisch et al., 2017). The authors concluded that sainfoin has great potential for cropping grass- 
legume mixtures with increased forage yields, especially when cutting frequency and $\mathrm{N}$ fertilizer input are low. These results indicate that sainfoin is relevant to local production of high-protein forage without applying excessive $\mathrm{N}$ fertilization leading ultimately to $\mathrm{N}_{2} \mathrm{O}$ emissions.

When ensiled with grass, sainfoin preserves silage quality via increased fermentation intensity and reduction in protein degradation in the silos (Copani et al., 2014). This was shown by a lower proportion of soluble $\mathrm{N}$ and ammonia (relative to total $\mathrm{N}$ ) in silage compared to grass silage, which reduces $\mathrm{N}$ losses in fermentation juices towards the environment.

At the animal level, the decrease in $\mathrm{CH}_{4}$ yield $(\mathrm{g} / \mathrm{kg} \mathrm{DMl})$ and changes in $\mathrm{N}$ partition when sainfoin is incorporated in the diet were consistently observed in sheep (Niderkorn et al., 2019) and dairy cows (Huyen et al., 2016a). A particularly interesting result was obtained in dairy cows when a sainfoincontaining diet reduced $\mathrm{CH}_{4}$ yield and diet digestibility of fibre, but improved milk yield compared to the same diet in which sainfoin was replaced by grass. The authors hypothesized that sainfoin may redirect metabolism towards body protein accretion at the expense of body fat (Huyen et al., 2016a). Sainfoincondensed tannins were shown to have anthelmintic activities in both small (Hoste et al., 2015) and large ruminants (Desrues et al., 2016), showing that a large spectrum of these compounds counteracts infection by gastrointestinal nematodes. This effect may help to decrease GHG emissions by animals, as shown by recent results indicating that parasitism increases $\mathrm{CH}_{4}$ emissions in sheep (Fox et al., 2018; Lima et al., 2019).

\subsection{Additive effect of different anti-methanogenic dietary strategies, a proof of concept}

Lipids have emerged as a persistent option for mitigating enteric $\mathrm{CH}_{4}$ emissions from ruminants (Doreau et al., 2014). However, their potential mitigation is moderate ( $20 \%)$ if used at a suitable dose avoiding negative effects on animal performance (see section 3.1).

As proof of concept, we tested whether it was possible to increase the $\mathrm{CH}_{4}$-mitigation potential of lipids (linseed oil) by combining them with another dietary strategy (nitrate) with a different mode of action on the metabolism of $\mathrm{H}_{2}$ in the rumen. In a meta-analysis, we reported that lipids may be relevant in reducing $\mathrm{H}_{2}$ production (via reduction of protozoa), whereas nitrate may stimulate $\mathrm{H}_{2}$ consumption $\left(\mathrm{H}_{2}\right.$ sink) by a competitive pathway to methanogenesis (Guyader et al., 2014). We assumed that simultaneous manipulation of $\mathrm{H}_{2}$ production and $\mathrm{H}_{2}$ utilization allows a greater reduction in $\mathrm{CH}_{4}$ emissions than when acting on a single pathway. To test this hypothesis, we tested the effect of linseed oil and nitrate fed alone or in combination on $\mathrm{CH}_{4}$ emissions and digestive processes in non-lactating cows.

The daily kinetics of $\mathrm{CH}_{4}$ emission measurements clearly showed an additive effect of the dietary strategies $(-32 \%$ reduction for linseed + nitrate vs. $-17 \%$ and $-22 \%$ reduction for linseed and nitrate fed alone, respectively). Linseed oil supplementation reduced $\mathrm{CH}_{4}$ emissions throughout the day compared to the control diet, while nitrate had a transient but marked action for 3-h post-feeding. Combination of the strategies cumulated the two modes of actions (Fig. 3).

In addition, we showed that linseed oil plus nitrate fed to lactating cows for 2 months induced a constant reduction of $\mathrm{CH}_{4}$ emissions ( $\left.-29 \% \mathrm{~g} / \mathrm{kg} \mathrm{DMI}\right)$, without any effect on digestibility of nutrients, $\mathrm{N}$ balance and milk performance. This persistent effect showed the absence of adaptation of rumen microbiota. However, the energetic benefits from the decreased $\mathrm{CH}_{4}$ emissions did not appear beneficial for the dairy cows (Guyader et al., 2016). 


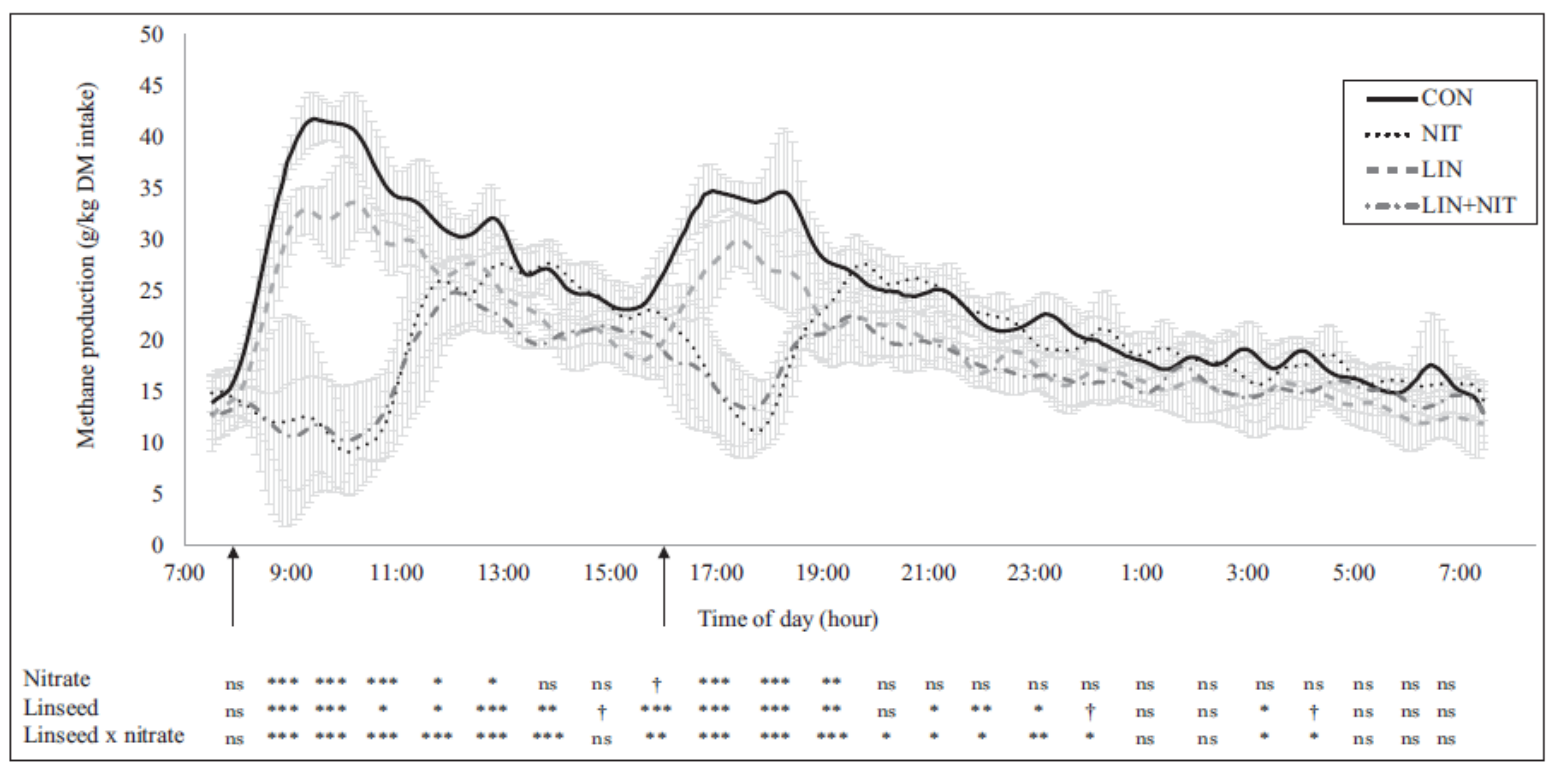

Figure 3 Daily methane production pattern of non-lactating cows fed four different diets containing linseed oil and calcium nitrate alone or in association $(n=4)$. Treatments consisted of control diet $(C O N)$, CON plus $3 \%$ calcium nitrate (NIT), CON plus $4 \%$ linseed oil (LIN) and CON plus $4 \%$ linseed oil and $3 \%$ calcium nitrate (LIN+NIT). The arrows indicate time of feeding. Error bars indicate SD. Adapted from Guyader et al. (2015).

Our work confirmed the initial working hypothesis that combining dietary strategies with different mechanisms of action to reduce $\mathrm{H}_{2}$ availability in the rumen reduces methanogenesis more markedly than when lipids are fed individually. This opens up the range of possibilities for designing new strategies to increase $\mathrm{CH}_{4}$ abatement (Beauchemin et al., 2020).

\section{Outstanding questions/future trends in research}

Considering the current health crisis, integrating animal production into a 'one health' approach is more relevant than ever: health care for humans, animalsand earth is important to consider in a systemic and integrated way at local, national and global levels. In this context, the use of plant bioactive substances from local resources in animal nutrition is a strong 'card to play' for promoting efficient and safe livestock farming to feed populations, while minimizing its environmental impact.

Many feed resources contain lipids and secondary compounds that are likely, if used properly, to improve animal performances and health, decrease enteric $\mathrm{CH}_{4}$ emissions and $\mathrm{N}$ waste, and improve the quality of animal products. However, many questions have to be addressed before widespread application at farm level. One demand of stakeholders concerns the possibility of standardized resources with a guaranteed content in active principle. This implies further research to characterize active molecules and their mode of action in order to design and evaluate new feeding strategies more efficient to minimize GHG emissions from ruminants.

Evaluation of new resources only on the traditional feed value is not sufficient. A multicriteria approach of these resources, as well as practices (crop growing, conservation, processing, feed delivery), is required to consider all animal responses, without neglecting evaluation of the cost-benefit ratio for farmers. Another challenge is to develop resources with valuable properties for pasture-based systems in order to better integrate the context of agroecological ruminant production. 


\section{Where to look for further information}

\subsection{Key articles or books}

- Vasta, V., Daghio, M., Cappucci, A., Buccioni, A., Serra, A., et al. 2019. Invited review: Plant polyphenols and rumen microbiota responsible for fatty acid biohydrogenation, fiber digestion, and methane emission: Experimental evidence and methodological approaches. J. Dairy Sci. 102, 3781-3804. https://doi.org /10.3168/jds.2018 -14985. - Mueller-Harvey, I., Bee, G., Dohme-Meier, F., Hoste, H., Karonen, M., Kölliker, R., Lüscher, A., Niderkorn, V., Pellikaan, W. F., Salminen, J. P., Skøt, L., Smith, L. M. J., Thamsborg, S. M., Totterdell, P., Wilkinson, I., Williams, A. R., Azuhnwi, B. N., Baert, N., Grosse Brinkhaus, A., Copani, G., Desrues, O., Drake, C., Engström, M., Fryganas, C., Girard, M., Huyen, N. T., Kempf, K., Malisch, C., Mora-Ortiz, M., Quijada, J., Ramsay, A., Ropiak, H. M., Waghorn, G. C. 2018. Benefits of condensed tannins in forage legumes fed to ruminants: importance of structure, concentration and diet composition. Invited review. Crop Science, 59, 861-885. https://doi.org/10.2135/cropsci2017.06 .0 369.

- Cobellis, G., Trabalza-Marinuccia, M., Yu, Z., 2016. Critical evaluation of essential oils as rumen modifiers in ruminant nutrition: A review. Sci. Total Environ. 545-546, 556-568. http://dx.doi.org/10.1016/j.scitotenv.2015.12.103.

- Hristov, A. N., Oh, J., Firkins, J. L., Dijkstra, Kebreab, J. E., Waghorn, G., et al. 2013b. Special topics-Mitigation of methane and nitrous oxide emissions from animal operations: I. A review of enteric methane mitigation options. J. Anim. Sci. 91, 5045-5069. https://doi.org /10.2527/jas.2013 -6583.

- Beauchemin, K. A., Ungerfeld, E. M., Eckard, R. J., Wang, M. 2020. Review: Fifty years of research on rumen methanogenesis: Lessons learned and future challenges for mitigation. Animal, 14:S1, s2-s16. https://doi.org /10.1 $017 / \mathrm{S} 1751731119003100$.

\subsection{Key conferences}

- International Symposium on the Nutrition of Herbivores, Clermont-Ferrand, FRA (2018-09-02-2018-09-06). Proceedings of the 10th International Symposium on the Nutrition of Herbivores in Advances in Animal Biosciences, 9(3), 337-786. doi:10.1017/S2040470018000146.

- International Symposium on Ruminant Physiology, Leipzig, DEU (2019-09-03-2019-09-06). Proceedings of the XIIIth International Symposium on Ruminant Physiology in Advances in Animal Biosciences, 10(3), 369-649.

doi:10.1017/S2040470019000037.

- Greenhouse Gases and Animal Agriculture conference, Iguassu, BRA (2019-08-04-2019-08-10). Proceedings of the VIIth Greenhouse Gas and Animal Agriculture Conference. http://www.ggaa 2019.org/sites/default/files/proceedings-ggaa 2019.pdf.

\subsection{Major international research projects and networks}

- LegumePlus (2012-2015): European project aiming to optimize plant polyphenols in legumes for ruminant nutrition plus health plus environmental sustainability (Project Number PITN-GA-2011-289377).

- Pro YoungStock (2018-2021): European CORE organic Co-fund project aiming to collect, to develop and to assess natural feeding strategies increasing dairy livestock welfare (Preject FiBL 50090).

- SmartCow (2018-2022): European project on infrastructures for increased research capability and innovation in the European cattle sector. Joint research activities are focused to improve the quality and ethics of research services through advances in the capabilities to investigate feed efficiency and emissions in cattle at a large scale and to valorize data from sensors monitoring nutrition, health and behaviour. 


\section{References}

Addisu, S. and Assefa, A. 2016. Role of plant containing saponin on livestock production: a review. Adv. Biol. Res. 10:309-314. doi:10.5829/idosi.abr.2016.309.314

Aemiro, A., Hanada, M., Umetsu, K. and Nishida, T. 2016. The effect of sunphenon 30S-Oon methane emission, nutrient intake, digestibility and rumen fermentation. Anim. Feed Sci. Tech. 214:34-43. doi:10.1016/j.anifeedsci.2016.02.007.

Archimède, H., Rira, M., Barde, D. J., Labirin, F., Marie - Magdeleine, C., Calif, B., Periacarpin, F., Fleury, J., Rochette, Y., Morgavi, D. P. and Doreau, M. 2016. Potential of tannin-rich plants, Leucaena leucocephala, Glyricidia sepium and Manihot esculenta, to reduce enteric methane emissions in sheep. J. Anim. Physiol. Anim. Nutr. 100(6):1149-1158.

Aufrère, J., Dudilieu, M. and Poncet, C. 2008. In vivo and in situ measurements of the digestive characteristics of sainfoin in comparison with Lucerne fed to sheep as fresh forages at two growth stages and as hay. Animal 2(9):1331-1339.

Baert, N., Pellikaan, W. F., Karonen, M. and Salminen, J. P. 2016. A study of the structureactivity relationship of oligomeric ellagitannins on ruminal fermentation in vitro. J. Dairy Sci. 99(10):8041-8052.

Bayat, A. R., Tapio, I., Vilkki, J., Shingfield, K. J. and Leskinen, H. 2018. Plant oil supplements reduce methane emissions and improve milk fatty acid composition in dairy cows fed grass silage-based diets without affecting milk yield. J. Dairy Sci. 101(2):1136-1151. doi:10.3168/jds.2017-13545.

Beauchemin, K. A. and McGinn, S. M. 2006. Methane emissions from beef cattle: effects of fumaric acid, essential oil, and canola oil. J. Anim. Sci. 84(6):1489-1496. doi:10.2527/2006.8461489x.

Beauchemin, K. A., Ungerfeld, E. M., Eckard, R. J. and Wang, M. 2020. Review: fifty years of research on rumen methanogenesis: lessons learned and future challenges for mitigation. Animal 14(S1):s2-s16. doi:10.1017/S1751731119003100.

Becker, P. M., van Wikselaar, P. G., Franssen, M. C. R., de Vos, R. C. H., Hall, R. D. and Beekwilder, J. 2014. Evidence for a hydrogen-sink mechanism of (+)catechinmediated emission reduction of the ruminant greenhouse gas methane. Metabolomics 10(2):179-189. doi:10.1007/s11306-013-0554-5.

Belanche, A., Newbold, C. J., Morgavi, D. P., Bach, A., Zweifel, B. and Yáñez-Ruiz, D. R. 2020. A meta-analysis describing the effects of the essential oils blend agolin ruminant on performance, rumen fermentation and methane emissions in dairy cows. Animals 10(4):620. doi:10.3390/ani10040620.

Benchaar, C. 2015. Diet supplementation with cinnamon oil, cinnamaldehyde, or monensin does not reduce enteric methane production of dairy cows. Animal 10(3):418-425. doi:10.1017/S175173111500230X.

Benchaar, C. and Greathead, H. 2011. Essential oils and opportunities to mitigate enteric methane emissions from ruminants. Anim. Feed Sci. Tech. 166-167:338-355. doi:10.1016/j.anifeedsci.2011.04.024.

Benchaar, C., Hassanat, F. and Petit, H. V. 2015. Dose-response to eugenol supplementation to dairy cow diets: methane production, $\mathrm{N}$ excretion, ruminal fermentation, nutrient digestibility, milk production, and milk fatty acid profile. Anim. Feed Sci. Tech. 209:51-59. doi:10.1016/j.anifeedsci.2015.07.027.

Bouwman, A. F. 1996. Direct emission of nitrous oxide from agricultural soils. Nutr. Cycl. Agroecosyst. 46(1):53-70. doi:10.1007/BF00210224.

Branco, A. F., Giallongo, F., Frederick, T., Weeks, H., Oh, J. and Hristov, A. N. 2015. Effect of technical cashew nut shell liquid on rumen methane emission and lactation performance of dairy cows. J. Dairy Sci. 98(6):4030-4040. doi:10.3168/ jds.2014-9015.

Buccioni, A., Pauselli, M., Viti, C., Minieri, S., Pallara, G., Roscini, V., Rapaccini, S., Marinucci, M. T., Lupi, P., Conte, G. and Mele, M. 2015. Milk fatty acid composition, rumen microbial population, and animal performances in response to diets rich in linoleic acid supplemented with chestnut or quebracho tannins in dairy ewes. J. Dairy Sci. 98(2):1145-1156. doi:10.3168/jds.20148651.

Calsamiglia, S., Busquet, M., Cardozo, P. W., Castillejos, L. and Ferret, A. 2007. Invited review: essential oils as modifiers of rumen microbial fermentation. J. Dairy Sci. 90(6):2580-2595. doi:10.3168/jds.2006-644.

Chung, Y. -H., He, M. L., McGinn, S. M., McAllister, T. A. and Beauchemin, K. A. 2011. Linseed suppresses enteric methane emissions from cattle fed barley silage, but not from those fed grass hay. Anim. Feed Sci. Technol. 166-167:321-329.

Cobellis, G., Trabalza-Marinucci, M. and Yu, Z. 2016. Critical evaluation of essential oils as rumen modifiers in ruminant nutrition: a review. Sci. Total Environ. 545-546:556-568. doi:10.1016/j.scitotenv.2015.12.103.

Copani, G., Ginane, C., Le Morvan, A. and Niderkorn, V. 2014. Bioactive forage legumes as a strategy to improve silage quality and minimise nitrogenous losses. Anim. Prod. Sci. 54(10):1826-1829. 
Costa, M., Alves, S. P., Cappucci, A., Cook, S. R., Duarte, A., Caldeira, R. M., McAllister, T. A. and Bessa, R. J. B. 2018. Effects of condensed and hydrolyzable tannins on rumen metabolism with emphasis on the biohydrogenation of unsaturated fatty acids. J. Agric. Food Chem. 66(13):3367-3377. doi:10.1021/acs.jafc.7b04770.

Czerkawski, J. W. 1986. An Introduction to Rumen Studies, Pergamon Press, Oxfordshire and New York.

De Klein, C. A. M. and Eckard, R. J. 2008. Targeted technologies for nitrous oxide abatement from animal agriculture. Aust. J. Exp. Agric. 48(2):14-20.

Desrues, O., Peña-Espinoza, M., Hansen, T. V. A., Enemark, H. L. and Thamsborg, S. M. 2016. Anti-parasitic activity of pelleted sainfoin (Onobrychis viciifolia) against Ostertagia ostertagi and Cooperia Oncophora in calves. Parasites Vectors 9(1):329.

Doreau, M., Bamière, L., Pellerin, S., Lherm, M. and Benoit, M. 2014. Mitigation of enteric methane for French cattle: potential extent and cost of selected actions. Anim. Prod. Sci. 54(9):1417-1422. doi:10.1071/AN14207.

Doreau, M., Martin, C., Eugène, M., Popova, M. and Morgavi, D. P. 2011. Leviers d'action pour réduire la production de méthane entérique par les ruminants. INRA Prod.Anim. 24(5):461-474. doi:1 0.208 70/pr oduct ions- anima les.2 011.2 4.5.3 278.

Dubois, B., Tomkins, N., Kinley, R. D., Bai, M., Seymour, S., Paul, N. and de Nys, R. 2013. Effect of tropical algae as additives on rumen in vitro gas production and fermentation characteristics. Am. J. Plant Sci. 4:34-43. doi:10.4236/ajps.2013.412A2005.

Engström, M. T., Arvola, J., Nenonen, S., Virtanen, V. T. J., Leppä, M. M., Tähtinen, P. and Salminen, J. -P. 2019. Structural features of hydrolysable tannins determine their ability to form insoluble complexes with bovine serum albumin. J. Agric. Food Chem. 67(24):6798-6808.

Eugène, M., Benchaar, C., Chiquette, J. and Masse, D. 2008. Meta-analysis on the effects of lipid supplementation on methane emissions and milk performance of lactating dairy cows. Can. J. Anim. Sci. 84:331-334.

Eugène, M., Doreau, M., Archimède, H., Giger-Reverdin, S. and Sauvant, D. 2019. Modelling by meta-analysis enteric methane emissions from ruminants fed forages supplemented or not with tannins. International Workshop on Modelling Nutrient

Digestion and Utilization in Farm Animals, Itamambuca Eco Resort, Brazil.

Fox, N. J., Smith, L. A., Houdijk, J. G. M., Athanasiadou, S. and Hutchings, M. R. 2018. Ubiquitous parasites drive a 33\% increase in methane yield from livestock. Int. J. Parasitol. 48(13):1017-1021. doi:10.1016/j.ijpara.2018.06.001.

Francis, G., Kerem, Z., Makkar, H. P. S. and Becker, K. 2007. The biological action of saponins in animal systems: a review. Br. J. Nutr. 88(6):587-605. doi:10.1079/BJN2002725.

Gerber, P. J., Hristov, A. N., Henderson, B., Makkar, H., Oh, J., Lee, C., Meinen, R., Montes, F., Ott, T., Firkins, J., Rotz, A., Dell, C., Adesogan, A. T., Yang, W. Z., Tricarico, J. M., Kebreab, E., Waghorn, G., Dijkstra, J. and Oosting, S. 2013. Technical options for the miti-gation of direct methane and nitrous oxide emissions from livestock-a review. Animal 7(S2):220-234. doi:10.1017/S1751731113000876.

Giger-Reverdin, S., Morand-Fehr, P. and Tran, G. 2003. Literature survey of the influence of dietary fat composition on methane production in dairy cattle. Livest. Prod. Sci. 82(1):73-79. doi:10.1016/S0301-6226(03)00002-2.

Grainger, C. and Beauchemin, K. A. 2011. Can enteric methane emissions from ruminants be lowered without lowering their production? Anim. Feed Sci. Technol. 166-167:308-320. doi:10.1016/j.anifeedsci.2011.04.021.

Guyader, J., Doreau, M., Morgavi, D. P., Gérard, C., Loncke, C. and Martin, C. 2016. Longterm effect of linseed plus nitrate fed to dairy cows on enteric methane emission and nitrate and nitrite residuals in milk. Animal 10(7):1173-1181. doi:10.1017/S1751731115002852.

Guyader, J., Eugène, M., Doreau, M., Morgavi, D. P., Gérard, C. and Martin, C. 2017. Tea saponin reduced methanogenesis in vitro but increased methane yield in lactating dairy cows. J. Dairy Sci. 100(3):1845-1855. doi:10.3168/jds.2016-11644.

Guyader, J., Eugène, M., Meunier, B., Doreau, M., Morgavi, D. P., Silberberg, M., Rochette, Y., Gerard, C., Loncke, C. and Martin, C. 2015. Additive methane-mitigating effect between linseed oil and nitrate fed to cattle. J. Anim. Sci. 93(7):3564-3577.

doi:10.2527/jas2014-8196.

Guyader, J., Eugène, M., Nozière, P., Morgavi, D. P., Doreau, M. and Martin, C. 2014. Influence of rumen protozoa on methane emissions in ruminants: a meta-analysis approach. Animal 8(11):1816-1825. doi:10.1017/S1751731114001852.

Hart, K. J., Yáñez-Ruiz, D. R., Duval, S. M., McEwan, N. R. and Newbold, C. J. 2008. Plant extracts to manipulate rumen fermentation. Anim. Feed Sci. Tech. 147(1-3):8-35.

Hatew, B., Stringano, E., Mueller - Harvey, I., Hendriks, W. H., Carbonero, C. H., Smith, L. M. J. and Pellikaan, W. F. 2016. Impact of variation in structure of condensed tannins from sainfoin (O nobrychis viciifolia) on in vitro ruminal methane production and fermentation characteristics. J. Anim. Physiol. Anim. Nutr. 100(2):348-360. 
Hollmann, M., Powers, W. J., Fogiel, A. C., Liesman, J. S., Bello, N. M. and Beede, D. K. 2012. Enteric methane emissions and lactational performance of Holstein cows fed different concentrations of coconut oil. J. Dairy Sci. 95(5):2602-2615.

Holtshausen, L., Chaves, A. V., Beauchemin, K. A., McGinn, S. M., McAllister, T. A., Odongo, N. E., Cheeke, P. R. and Benchaar, C. 2009. Feeding saponin-containing Yucca schidigera and Quillaja Saponaria to decrease enteric methane production in dairy cows. J. Dairy Sci. 92(6):2809-2821. doi:10.3168/jds.2008-1843.

Hoste, H., Torres-Acosta, J. F., Sandoval-Castro, C. A., Mueller-Harvey, I., Sotiraki, S., Louvandini, H., Thamsborg, S. M. and Terrill, T. H. 2015. Tannin containing legumes as a model for nutraceuticals against digestive parasites in livestock. Vet. Parasitol. 212(1-2):5-17. doi:10.1016/j.vetpar.2015.06.026.

Hristov, A. N., Lee, C., Cassidy, T., Heyler, K., Tekippe, J. A., Varga, G. A., Corl, B. and Brandt, R. C. 2013a. Effect of Origanum vulgare L. leaves on rumen fermentation, production, and milk fatty acid composition in lactating dairy cows. J. Dairy Sci. 96(2):1189-1202. doi:10.3168/jds.2012-5975.

Hristov, A. N., Oh, J., Firkins, J. L., Dijkstra, J., Kebreab, E., Waghorn, G., Makkar, H. P., Adesogan, A. T., Yang, W., Lee, C., Gerber, P. J., Henderson, B. and Tricarico, J. M. 2013b. Special topics—mitigation of methane and nitrous oxide emissions from animal operations: I. A review of enteric methane mitigation options. J. Anim. Sci. 91(11):5045-5069. doi:10.2527/jas.2013-6583. Huyen, N. T., Desrues, O., Alferink, S. J. J., Zandstra, T., Verstegen, M. W. A., Hendriks, W. H. and Pellikaan, W. F. 2016a. Inclusion of sainfoin (Onobrychis viciifolia) silage in dairy cow rations affects nutrient digestibility, nitrogen utilization, energy balance, and methane emissions. J. Dairy Sci. 99(5):3566-3577.

Huyen, N. T., Fryganas, C., Uittenbogaard, G., Mueller-Harvey, I., Verstegen, M. W. A., Hendriks, W. H. and Pellikaan, W. F. 2016b. Structural features of condensed tannins affect in vitro ruminal methane production and fermentation characteristics. $J$. Agric. Sci. 154(8):1474-1487.

INRA. 2018. INRA Feeding System for Ruminants, Wageningen Academic Publishers, Wageningen, the Netherlands.

Jayanegara, A., Goel, G., Makkar, H. P. S. and Becker, K. 2015. Divergence between purified hydrolysable and condensed tannin effects on methane emission, rumen fermentation and microbial population in vitro. Anim. Feed Sci. Technol. 209:60-68.

Jayanegara, A., Leiber, F. and Kreuzer, M. 2012. Meta - analysis of the relationship between dietary tannin level and methane formation in ruminants from in vivo and in vitro experiments. J. Anim. Physiol. Anim. Nutr. 96(3):365-375.

Jayanegara, A., Wina, E. and Takahashi, J. 2014. Meta-analysis on methane mitigating properties of saponin-rich sources in the rumen: influence of addition levels and plant sources. Asian Australas. J. Anim. Sci. 27(10):1426-1435.

Jentsch, W., Wittenburg, H. and Schiemann, R. 1972. Die Verwertung der Futterenergie fur die Milchproduction. 4. Unters. Verwertung Futterenergie Rapsoleinsatz Arch. Tierernahr. 22:697-720.

Ju, W. T., Kwon, O. C., Kim, H. B., Sung, G. B., Kim, H. W. and Kim, Y. S. 2018. Qualitative and quantitative analysis of flavonoids from 12 species of Korean mulberry leaves. J. Food. Sci. Technol. 55(5):1789-1796. doi:10.1007/s13197-018-3093-2.

Kang, S., Suzuki, R., Suzuki, Y., Koike, S., Nagashima, K. and Kobayashi, Y. 2018. Rumen responses to dietary supplementation with cashew nut shell liquid and its cessation in sheep. Anim. Sci. J. 89(11):1549-1555. doi:10.1111/asj.13100.

Keng, F. S., Phang, S., Abd Rahman, N., Leedham Elvidge, E. C., Malin, G. and Sturges, W. T. 2020. The emission of volatile halocarbons by seaweeds and their response towards environmental changes. J. Appl. Phycol. 32(2):1377-1394. doi:10.1007/ s10811-019-02026-x.

Kinley, R. D., de Nys, R., Vucko, M. J., Machado, L. and Tomkins, N. W. 2016. The red macroalgae Asparagopsis taxiformis is a potent natural antimethanogenic that reduces methane production during in vitro fermentation with rumen fluid. Anim. Prod. Sci. 56(3):282-289. doi:10.1071/AN15576.

Kinley, R. D. and Fredeen, A. H. 2015. In vitro evaluation of feeding North Atlantic stormtoss seaweeds on ruminal digestion. $J$. Appl. Phycol. 27(6):2387-2393. doi:10.1007/s10811-014-0487-z.

Kinley, R. D., Martinez-Fernandez, G., Matthews, M. K., de Nys, R., Magnusson, M. and Tomkins, N. W. 2020. Mitigating the carbon footprint and improving productivity of ruminant livestock agriculture using a red seaweed. J. Clean. Prod. 259. doi:10.1016/j.jclepro.2020.120836.

Klevenhusen, F., Zeitz, J. O., Duval, S., Kreuzer, M. and Soliva, C. R. 2011. Garlic oil and its principal component diallyl disulfide fail to mitigate methane, but improve digestibility in sheep. Anim. Feed Sci. Tech. 166-167:356-363.

Klita, P. T., Mathison, G. W., Fenton, T. W. and Hardin, R. T. 1996. Effects of alfalfa root saponins on digestive function in sheep. J. Anim. Sci. 74(5):1144-1156. 
Kolling, G. J., Stivanin, S. C. B., Gabbi, A. M., Machado, F. S., Ferreira, A. L., Campos, M. M., Tomich, T. R., Cunha, C. S., Dill, S. W., Pereira, L. G. R. and Fischer, V. 2018. Performance and methane emissions in dairy cows fed oregano and green tea extracts as feed additives. J. Dairy Sci. 101(5):4221-4234. doi:10.3168/jds.2017-13841.

Konda, S., Onodera, R., Kanchanasatit, E., Boonsaen, P., Sawanon, S., Nagashima, K., Suzuki, Y., Koike, S. and Kobayashi, Y. 2019. Effect of cashew nut shell liquid feeding on fermentation and microbiota in the rumen of Thai native cattle and swamp buffaloes. Livest. Sci. 226:99-106. doi:10.1016/j.livsci.2019.06.011.

Li, W. and Powers, W. 2012. Effects of saponin extracts on air emissions from steers. J. Anim. Sci. 90(11):4001-4013. doi:10.2527/jas.2011-4888.

Li, X., Norman, H. C., Kinley, R. D., Laurence, M., Wilmot, M., Bender, H., de Nys, R. and Tomkins, N. 2016. Asparagopsis taxiformis decreases enteric methane production from sheep. Anim. Prod. Sci. 58(4). doi:10.1071/AN15883.

Lima, PdM. T., Crouzoulon, P., Sanches, T. P., Zabré, G., Kabore, A., Niderkorn, V., Hoste, H., Amarante, A. F. Td, Costa-Júnior, L. M., Abdalla, A. L. and Louvandini, H. 2019. Effects of Acacia mearnsii supplementation on nutrition, parasitological, blood parameters and methane emissions in Santa Inês sheep infected with Trichostrongylus colubriformis and Haemonchus contortus. Exp. Parasitol. 207:107777.

Liu, H., Wang, J., Wang, A. and Chen, J. 2011. Chemical inhibitors of methanogenesis and putative applications. Appl. Microbiol. Biotechnol. 89(5):1333-1340. doi:10.1007/s00253-010-3066-5.

Luo, J. and Kelliher, F. M. 2010. Partitioning of Animal Excreta N into Urine and Dung and Developing the N2O Inventory. Report for the MAF Policy (MAF POL 0910-11528 09-03), Wellington.

Ma, T., Chen, D. D., Tu, Y., Zhang, N. F., Si, B. W., Deng, K. D. and Diao, Q. Y. 2016. Effect of supplementation of allicin on methanogenesis and ruminal microbial flora in Dorper crossbred ewes. J. Anim. Sci. Biotechnol. 7(1). doi:10.1186/s40104-0150057-5.

Ma, T., Chen, D. D., Tu, Y., Zhang, N. F., Si, B. W. and Diao, Q. Y. 2017. Dietary supplementation with mulberry leaf flavonoids inhibits methanogenesis in sheep. Anim. Sci. 88(1):72-78. doi:10.1111/asj.12556.

Machado, L., Magnusson, M., Paul, N. A., de Nys, R. and Tomkins, N. 2014. Effects of marine and freshwater macroalgae on in vitro total gas and methane production. PLOS ONE 9(1):e85289. doi:10.1371/journal.pone.0085289.

Machado, L., Magnusson, M., Paul, N. A., Kinley, R., de Nys, R. and Tomkis, N. 2016a. Dose-response effects of Asparagopsis taxiformis and Oedogonium sp. on in vitro fermentation and methane production. J. Appl. Phycol. 28(2):1443-1452. doi:10.1007/s10811-015-0639-9.

Machado, L., Magnusson, M., Paul, N. A., Kinley, R., de Nys, R. and Tomkis, N. 2016b. Identification of bioactives from the red seaweed Asparagopsis taxiformis that promote antimethanogenic activity in vitro. J. Appl. Phycol. 28(5):3117-3126. doi:10.1007/s10811-016-0830-7.

Machado, L., Tomkis, N., Magnusson, M., Midgley, D. J., de Nys, R. and Rosewarne, C. P. 2018. In vitro Response of Rumen microbiota to the Antimethanogenic Red Macroalga Asparagopsis taxiformis. Microb. Ecol. 75(3):811-818.

Macheboeuf, D., Morgavi, D. P., Papon, Y., Mousset, J. -L. and Arturo-Schaan, M. 2008. Dose-response effects of essential oils on in vitro fermentation activity of the rumen microbial population. Anim. Feed Sci. Tech. 145(1-4):335-350.

Machmüller, A. and Kreuzer, M. 1999. Methane suppression by coconut oil and associated effects on nutrient and energy balance in sheep. Can. J. Anim. Sci. 79(1):65-72.

Malisch, C. S., Suter, D., Studer, B. and Lüscher, A. 2017. Multifunctional benefits of sainfoin mixtures: effects of partner species, sowing density and cutting regime. Grass Forage Sci. 72(4):794-805.

Manasri, N., Wanapat, M. and Navanukraw, C. 2012. Improving rumen fermentation and feed digestibility in cattle by mangosteen peel and garlic pellet supplementation. Livest. Sci. 148(3):291-295. 10.1016/j.livsci.2012.06.009

Mao, H. L., Wang, J. K., Zhou, Y. Y. and Liu, J. X. 2010. Effects of addition of tea saponins and soybean oil on methane production, fermentation and microbial population in the rumen of growing lambs. Livest. Sci. 129(1-3):56-62. doi:10.1016/j. livsci.2009.12.011.

Martin, C., Ferlay, A., Mosoni, P., Rochette, Y., Chilliard, Y. and Doreau, M. 2016. Increasing linseed supply in dairy cow diets based on hay or corn silage: effect on enteric methane emission, rumen microbial fermentation, and digestion. J. Dairy Sci. 99(5):3445-3456. doi:10.3168/jds.2015-10110.

Martin, C., Morgavi, D. P. and Doreau, M. 2010. Methane mitigation in ruminants: from microbe to the farm scale. Animal 4(3):351365. doi:10.1017/S1751731109990620.

Martin, C., Pomiès, D., Ferlay, A., Rochette, Y., Martin, B., Chilliard, Y., Morgavi, D. P. and Doreau, M. 2011. Methane output and rumen microbiota in dairy cows in response to longterm supplementation with linseed or rapeseed of grass silage or pasture 
based diets. Proc. N. Z. Soc. Anim. Prod. 71:243-247.

Martin, C., Rouel, J., Jouany, J. P., Doreau, M. and Chilliard, Y. 2008. Methane output and diet digestibility in response to feeding dairy cows with crude linseed, extruded linseed or linseed oil. J. Anim. Sci. 86(10):2642-2650.

Mills, J. A., Dijkstra, J., Bannink, A., Cammell, S. B., Kebreab, E. and France, J. 2001. A mechanistic model of whole-tract digestion and methanogenesis in the lactating dairy cow: model development, evaluation, and application. J. Anim. Sci. 79(6):1584-1597.

Mitra, S. and Dungan, S. R. 1997. Micellar properties of Quillaja saponin. 1. Effects of temperature, salt, and pH on solution properties. J. Agric. Food Chem. 45(5):1587-1595.

Mohammed, N., Ajisaka, N., Lila, Z. A., Hara, K., Mikuni, K., Hara, K., Kanda, S. and Itabashi, H. 2004. Effect of Japanese horseradish oil on methane production and ruminal fermentation in vitro and in steers. J. Anim. Sci. 82(6):1839-1846.

Morgavi, D. P., Forano, E., Martin, C. and Newbold, C. J. 2010. Microbial ecosystem and methanogenesis in ruminants. Animal 4(7):1024-1036. doi:10.1017/S1751731110000546.

Mueller-Harvey, I. 2006. Unravelling the conundrum of tannins in animal nutrition and health. J. Sci. Food Agric. 86(13):20102037.

Mueller-Harvey, I., Bee, G., Dohme-Meier, F., Hoste, H., Karonen, M., Kölliker, R., Lüscher, A., Niderkorn, V., Pellikaan, W. F., Salminen, J., Skøt, L., Smith, L. M. J., Thamsborg, S. M., Totterdell, P., Wilkinson, I., Williams, A. R., Azuhnwi, B. N., Baert, N., Brinkhaus, A. G., Copani, G., Desrues, O., Drake, C., Engström, M., Fryganas, C., Girard, M., Huyen, N. T., Kempf, K., Malisch, C., Mora-Ortiz, M., Quijada, J., Ramsay, A., Ropiak, H. M. and Waghorn, G. C. 2019. Benefits of condensed tannins in forage legumes fed to ruminants: importance of structure, concentration, and diet composition. Crop Sci.59(3):861-885.

Newbold, C. J., El Hassan, S. M., Wang, J., Ortega, M. E. and Wallace, R. J. 1997. Influence of foliage from African multipurpose trees on activity of rumen protozoa and bacteria. Br. J. Nutr. 78(2):237-249.

Niderkorn, V., Copani, G., Martin, C., Maxin, G., Torrent, A., Anglard, F., Rochette, Y. and Ginane, C. 2019. Effects of including bioactive legumes in grass silage on digestion parameters, nitrogen balance and methane emissions in sheep. Grass Forage Sci. 74(4):626-635. doi:10.1111/gfs.12454.

Olagaray, K. E. and Bradford, B. J. 2019. Plant flavonoids to improve productivity of ruminants-a review. Anim. Feed Sci. Tech. 251:21-36. 10.1016/j. anifeedsci.2019.02.004

Palmquist, D. L. and Jenkins, T. C. 2017. A 100-year review: fat feeding of dairy cows. J. Dairy Sci. 100(12):10061-10077. doi:10.3168/jds.2017-12924.

Panthee, A., Matsuno, A., Al-Mamun, M. and Sano, H. 2017. Effect of feeding garlic leaves on rumen fermentation, methane emission, plasma glucose kinetics, and nitrogen utilization in sheep. J. Anim. Sci. Technol. 59(1):14. 10.1186/s40781-017-01393.

Patra, A. K., Kamra, D. N., Bhar, R., Kumar, R. and Agarwal, N. 2011. Effect of Terminalia chebula and Allium sativum on in vivo methane emission by sheep. J. Anim. Physiol. Anim. Nutr. (Berl) 95(2):187-191. doi:10.1111/j.1439-0396.2010.01039.x.

Patra, A. K. and Saxena, J. 2009. The effect and mode of action of saponins on the microbial populations and fermentation in the rumen and ruminant production. Nutr. Res. Rev. 22(2):204-219. doi:10.1017/S0954422409990163.

Patra, A. K. and Saxena, J. 2010. A new perspective on the use of plant secondary metabolites to inhibit methanogenesis in the rumen. Phytochemistry 71(11-12):1198-1222.

Patra, A. K. and Yu, Z. 2012. Effects of essential oils on methane production and fermentation by, and abundance and diversity of, rumen microbial populations. Appl. Environ. Microbiol. 78(12):4271-4280. doi:10.1128/aem.00309-12.

Pen, B., Takaura, K., Yamaguchi, S., Asa, R. and Takahashi, J. 2007. Effects of Yucca schidigera and Quillaja Saponaria with or without $\beta$ 1-4 galacto-oligosaccharides on ruminal fermentation, methane production and nitrogen utilization in sheep. Anim.

Feed Sci. Technol. 138(1):75-88. doi:10.1016/j.anifeedsci.2006.11.018.

Piluzza, G., Sulas, L. and Bullitta, S. 2014. Tannins in forage plants and their role in animal husbandry and environmental sustainability: a review. Grass Forage Sci. 69(1):32-48. doi:10.1111/gfs.12053.

Popova, M., Morgavi, D. P., Doreau, M. and Martin, C. 2011. Production de méthane et interactions microbiennes dans le rumen. INRA Prod. Anim. 24(5):447-460. doi:10.208 70/pr oduct ions- anima les.2 011.2 4.5.3277.

Powell, J. M., Aguerre, M. J. and Wattiaux, M. A. 2011. Tannin extracts abate ammonia emissions from simulated dairy barn floors. J. Environ. Qual. 40(3):907-914. doi:10.2134/jeq2010.0492.

Ramos-Morales, E., de la Fuente, G., Nash, R. J., Braganca, R., Duval, S., Bouillon, M. E., Lahmann, M. and Newbold, C. J. 2017. Improving the antiprotozoal effect of saponins in the rumen by combination with glycosidase inhibiting iminosugars or by modification of their chemical structure. PLOS ONE 12(9):e0184517. doi:10.1371/journal.pone.0184517. 
Reed, J. D. 1995. Nutritional toxicology of tannins and related polyphenols in forage legumes. J. Anim. Sci. 73(5):1516-1528. doi:10.2527/1995.7351516x.

Rira, M., Morgavi, D. P., Genestoux, L., Djibiri, S., Sekhri, I. and Doreau, M. 2019. Methanogenic potential of tropical feeds rich in hydrolyzable tannins1,2. J. Anim.Sci. 97(7):2700-2710.

Roque, B. M., Salwen, J. K., Kinley, R. and Kebreab, E. 2019a. Inclusion of Asparagopsis armata in lactating dairy cows' diet reduces enteric methane emission by over 50 percent. J. Clean. Prod. 234:132-138. doi:10.1016/j.jclepro.2019.06.193.

Roque, B. M., Van Lingen, H. J., Vrancken, H. and Kebreab, E. 2019b. Effect of Mootral-a garlic- and citrus-extract-based feed additive—on enteric methane emissions in feedlot cattle. Transl. Anim. Sci. 3(4):1383-1388. 10.1093/tas/txz133

Saminathan, M., Sieo, C. C., Gan, H. M., Abdullah, N., Wong, C. M. V. L. and Ho, Y. W. 2016. Effects of condensed tannin fractions of different molecular weights on population and diversity of bovine rumen methanogenic archaea in vitro, as determined by high-throughput sequencing. Anim. Feed Sci. Technol. 216:146-160.

Santoso, B., Mwenya, B., Sar, C., Gamo, Y., Kobayashi, T., Morikawa, R. and Takahashi, J. 2004. Effect of Yucca schidigera with or without nisin on ruminal fermentation and microbial protein synthesis in sheep fed silage- and hay-based diets. Anim. Sci. 75(6):525-531. doi:10.1111/j.1740-0929.2004.00223.x.

Saro, C., Hohenester, U. M., Bernard, M., Lagrée, M., Martin, C., Doreau, M., Boudra, H., Popova, M. and Morgavi, D. P. 2018. Effectiveness of interventions to modulate the rumen microbiota composition and function in pre-ruminant and ruminant lambs.

Front. Microbiol. 9:1273. 10.3389/fmicb.2018.01273

Sauvant, D., Giger-Reverdin, S. and Eugène, M. 2018. Émissions de méthane entérique. In: Nozière, P., Sauvant, D., Delaby, L. and INRA, (Eds.) Alimentation des ruminants. Apports nutritionnels - Besoins et réponses des animaux - Rationnement - Tables des valeurs des aliments. Federal Railroad Administration, Versailles, Editions Quae, pp. 243-247.

Selbie, D. R., Buckthought, L. E. and Shepherd, M. A. 2015. The challenge of the urine patch for managing nitrogen in grazed pasture systems. Adv. Agron. 129:229-292.

Shinkai, T., Enishi, O., Mitsumori, M., Higuchi, K., Kobayashi, Y., Takenaka, A., Nagashima, K., Mochizuki, M. and Kobayashi, Y. 2012. Mitigation of methane production from cattle by feeding cashew nut shell liquid. J. Dairy Sci. 95(9):5308-5316. doi:10.3168/ jds.2012-5554.

Soussana, J. F., Tichit, M., Lecomte, P. and Dumont, B. 2015. Agroecology: integration with livestock. In: Agroecology for Food Security and Nutrition Proceedings of the FAO International Symposium, 18-19 September 2014, Rome, Italy. Rome: FAO,

225-249. ISBN 978-92-5-108807-4. (International Symposium on Agroecology for Food Security and Nutrition, Rome, Italie, 18 Septembre 2014/19 Septembre 2014.) Available at: http://www .fao .org /3 /a -i4729e .pdf.

Stoldt, A. K., Derno, M., Das, G., Weitzel, J. M., Wolffram, S. and Metges, C. C. 2016. Effects of rutin and buckwheat seeds on energy metabolism and methane production in dairy cows. J. Dairy Sci. 99(3):2161-2168. doi:10.3168/jds.2015-10143.

Tekippe, J. A., Hristov, A. N., Heyler, K. S., Cassidy, T. W., Zheljazkov, V. D., Ferreira, J. F. S., Karnati, S. K. and Varga, G. A. 2011. Rumen fermentation and production effects of Origanum vulgare L. leaves in lactating dairy cows. J. Dairy Sci. 94(10):50655079. doi:10.3168/jds.2010-4095.

Theodoridou, K., Aufrère, J., Andueza, D., Pourrat, J., Le Morvan, A., Stringano, E., Mueller-Harvey, I. and Baumont, R. 2010. Effects of condensed tannins in fresh sainfoin (Onobrychis viciifolia) on in vivo and in situ digestion in sheep. Anim. Feed Sci. Technol. 160(1-2):23-38.

Tomkins, N. W., Denman, S. E., Pilajun, R., Wanapat, M., McSweeney, C. S. and Elliott, R. 2015. Manipulating rumen fermentation and methanogenesis using an essential oil and monensin in beef cattle fed a tropical grass hay. Anim. Feed Sci. Tech. 200:2534. doi:10.1016/j.anifeedsci.2014.11.013.

van Gastelen, S., Visker, M. H. P. W., Edwards, J. E., Antunes-Fernandes, E. C., Hettinga, K. A., Alferink, S. J. J., Hendriks, W. H., Bovenhuis, H., Smidt, H. and Dijkstra, J. 2017. Linseed oil and DGAT1 K232A polymorphism: effects on methane emission, energy and nitrogen metabolism, lactation performance, ruminal fermentation, and rumen microbial composition of HolsteinFriesian cows. J. Dairy Sci. 100(11):8939-8957. doi:10.3168/jds.2016-12367.

Vargas, J. E., Andrés, S., López-Ferreras, L., Snelling, T. J., Yáñez-Ruíz, D. R., García-Estrada, C. and López, S. 2020. Dietary supplemental plant oils reduce methanogenesis from anaerobic microbial fermentation in the rumen. Sci. Rep. 10(1):1613. doi:10.1038/s41598-020-58401-z.

Vasta, V., Daghio, M., Cappucci, A., Buccioni, A., Serra, A., Viti, C. and Mele, M. 2019. Invited review: plant polyphenols and rumen microbiota responsible for fatty acid biohydrogenation, fiber digestion, and methane emission: experimental evidence and methodological approaches. J. Dairy Sci. 102(5):3781-3804. doi:10.3168/jds.2018-14985. 
Veneman, J. B., Muetzel, S., Hart, K. J., Faulkner, C. L., Moorby, J. M., Perdok, H. B. and Newbold, C. J. 2015. Does dietary mitigation of enteric methane production affect rumen function and animal productivity in dairy cows? PLOS ONE 10: e0140282. Vincken, J. P., Heng, L., de Groot, A. and Gruppen, H. 2007. Saponins, classification and occurrence in the plant kingdom. Phytochemistry 68(3):275-297. doi:10.1016/j. phytochem.2006.10.008.

Vrancken, H., Suenkel, M., Hargreaves, P. R., Chew, L. and Towers,E. 2019. Reduction of enteric methane emission in a commercial dairy farm by a novel feed supplement. Open J. Anim. Sci. 09(3):286-296. doi:10.4236/ojas.2019.93024.

Wanapat, M., Chanthakhoun, V., Phesatcha, K. and Kang, S. 2014. Influence of mangosteen peel powder as a source of plant secondary compounds on rumen microorganisms, volatile fatty acids, methane and microbial protein synthesis in swamp buffaloes. Livest. Sci. 162:126-133. doi:10.1016/j.livsci.2014.01.025.

Wang, B., Ma, M. P., Diao, Q. Y. and Tu, Y. 2019. Saponin-induced shifts in the rumen microbiome and metabolome of young cattle. Front. Microbiol. 10. doi:10.3389/fmicb.2019.00356.

Wang, C. J., Wang, S. P. and Zhou, H. 2009. Influences of flavomycin, ropadiar, and saponin on nutrient digestibility, rumen fermentation, and methane emission from sheep. Anim. Feed Sci. Technol. 148(2-4):157-166. doi:10.1016/j.anifeedsci.2008.03.008.

Wina, E., Muetzel, S. and Becker, K. 2006. The dynamics of major fibrolytic microbes and enzyme activity in the rumen in response to short- and longterm feeding of Sapindus rarak saponins. J. Appl. Microbiol. 100(1):114-122. doi:10.1111/j.13652672.2005.02746.x.

Wink, M. 2015. Modes of action of herbal medicines and plant secondary metabolites. Medicines 2(3):251-286. doi:10.3390/medicines2030251.

Yang, K., Wei, C., Zhao, G. Y., Xu, Z. W. and Lin, S. X. 2017. Effects of dietary supplementing tannic acid in the ration of beef cattle on rumen fermentation, methane emission, microbial flora and nutrient digestibility. J. Anim. Physiol. Anim. Nutr. 101(2):302310. doi: 10.1111/jpn.12531. Epub 2016 Jun 8. PMID: 27272696.

Yuan, Z. P., Zhang, C. M., Zhou, L., Zou, C. X., Guo, Y. Q., Li, W., Liu, J. and Wu, Y. 2007. Inhibition of methanogenesis by tea saponin and tea saponin plus disodium fumarate in sheep. J. Anim. Feed Sci. 16(Suppl. 2):560-565.

Zeller, W. E. 2019. Activity, purification, and analysis of condensed tannins: current state of affairs and future endeavors. Crop Sci. 59(3):886-904.

Zhou, Y. Y., Mao, H. L., Jiang, F., Wang, J. K., Liu, J. X. and McSweeney, C. S. 2011. Inhibition of rumen methanogenesis by tea saponins with reference to fermentation pattern and microbial communities in Hu sheep. Anim. Feed Sci. Technol. 166-167:93100. doi:10.1016/j.anifeedsci.2011.04.007. 